Article

\title{
Silver-Containing Thin Films on Transparent Polymer Foils for Antimicrobial Applications
}

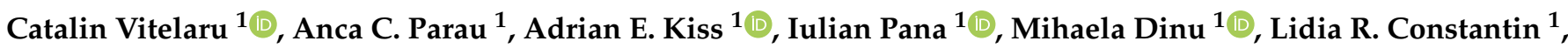 \\ Alina Vladescu ${ }^{1,2, * \mathbb{C}}$, Lavinia E. Tonofrei ${ }^{3}$, Cristina S. Adochite ${ }^{4, *(\mathbb{D}}$, Sarah Costinas ${ }^{4}$, Liliana Rogozea ${ }^{4} \mathbb{D}_{\text {, }}$ \\ Mihaela Badea ${ }^{4}\left(\mathbb{D}\right.$ and Mihaela E. Idomir ${ }^{4}$
}

1 National Institute for Research and Development in Optoelectronics INOE 2000, Strada Atomiștilor 409, 077125 Măgurele, Romania; catalin.vitelaru@inoe.ro (C.V.); anca.parau@inoe.ro (A.C.P.); kadremil@yahoo.com (A.E.K.); iulian.pana@inoe.ro (I.P.); mihaela.dinu@inoe.ro (M.D.); lidia.constantin@inoe.ro (L.R.C.)

2 Research Center for Physical Materials Science and Composite Materials, Research School of Chemistry \& Applied Biomedical Sciences, Tomsk Polytechnic University, Lenin's Avenue 43, 634050 Tomsk, Russia

3 ATS Novus SRL, 030352 Bucharest, Romania; lavinia.voinea@gmail.com

4 Faculty of Medicine, Transilvania University of Brasov, B-dul Eroilor nr 29, 500036 Brașov, Romania; sarah.costinas@gmail.com (S.C.); r_liliana@yahoo.com (L.R.); mihaela.badea@unitbv.ro (M.B.); mihaela.idomir@unitbv.ro (M.E.I.)

* Correspondence: alinava@inoe.ro (A.V.); cristina.adochite@unitbv.ro (C.S.A.)

check for updates

Citation: Vitelaru, C.; Parau, A.C.;

Kiss, A.E.; Pana, I.; Dinu, M.;

Constantin, L.R.; Vladescu, A.;

Tonofrei, L.E.; Adochite, C.S.;

Costinas, S.; et al. Silver-Containing

Thin Films on Transparent Polymer

Foils for Antimicrobial Applications. Coatings 2022, 12, 170. https://

doi.org/10.3390/coatings12020170

Academic Editor: Jeff Rao

Received: 13 December 2021

Accepted: 25 January 2022

Published: 28 January 2022

Publisher's Note: MDPI stays neutral with regard to jurisdictional claims in published maps and institutional affiliations.

Copyright: (C) 2022 by the authors. Licensee MDPI, Basel, Switzerland. This article is an open access article distributed under the terms and conditions of the Creative Commons Attribution (CC BY) license (https:// creativecommons.org/licenses/by/ $4.0 /)$.

\begin{abstract}
The increasing occurrence of infections caused by pathogens found on objects of everyday use requires a variety of solutions for active disinfection. Using active materials that do not require daily maintenance has a potential advantage for their acceptance. In this contribution, transparent films, with silver as the main antimicrobial agent and a total thickness of a few tens of nm, were deposited on flexible self-adhesive polymer foils used as screen protectors. $\mathrm{TiO}_{2}$ and $\mathrm{SiO}_{2}$ were used as transparent matrix to embed the Ag nanoparticles, ensuring also their mechanical protection and controlled growth. HiPIMS (High-Power Impulse Magnetron Sputtering) was used for the sputtering of the Ag target and fine control of the Ag amount in the layer, whereas $\mathrm{TiO}_{2}$ and $\mathrm{SiO}_{2}$ were sputtered in RF (Radio Frequency) mode. The thin film surface was investigated by AFM (Atomic Force Microscopy), providing information on the topography of the coatings and their preferential growth on the textured polymer foil. XRD (X-Ray Diffraction) revealed the presence of specific Ag peaks in an amorphous oxide matrix. UV-Vis-NIR (Ultraviolet-Visible-Near Infrared) spectroscopy revealed the presence of nanostructured $\mathrm{Ag}$, characterized by preferential absorption in the 400 to $500 \mathrm{~nm}$ spectral range. The antimicrobial properties were assessed using an antimicrobial test with the Escherichia coli strain. The highest efficiency was observed for the $\mathrm{Ag} / \mathrm{SiO}_{2}$ combination, in the concentration range of $10^{4}-10^{5} \mathrm{CFU} / \mathrm{mL}$.
\end{abstract}

Keywords: antimicrobial; silver; magnetron sputtering; polymer foils

\section{Introduction}

Pathogenic infectious agents capable of forming biofilms survive on surfaces for long periods of time. It is known that some multidrug-resistant bacterial strains such as MRSA (Methicillin-resistant Staphylococcus aureus) and VRE (Vancomycin-resistant Enterococci) can survive for weeks on various surfaces in the hospital [1-3]. The use of disinfectants for various surfaces is the most common solution but is associated with some disadvantages related to the fact that they must be used in certain concentrations with varying degrees of toxicity. If applied incorrectly, their bactericidal activity is short-lived, recontamination being possible in a few minutes [4]. Therefore, it is desired to introduce films with longterm antibacterial properties on frequently touched surfaces, such as the screens of various devices (telephones, medical equipment, computers, etc.). 
Ever since cellular phone introduction in the 1980s, there has been a continuous increase in its popularity around the world, with an estimated number of 4.5 billion people (60\% of the global population) owning such a device between 2016 and 2017. The increase was accelerated after the introduction of smartphones in 2012, with an estimated 2.3 billion owners [5]. While using a mobile phone, the device comes into contact with contaminated areas of the human body, like the hands, or more sensitive areas like the mouth, nose, and eyes [6]. The mobile phone, which has become an essential part of human life, is therefore a very sensitive device when it comes to possible contaminations, and the use of touch screens only prolongs the contact with the skin and increases the probability of contamination [7].

Silver nanoparticles are widely used as potent antimicrobial agents in various applications $[8,9]$. By embedding them into a transparent dielectric matrix, it is possible to obtain coatings that are both transparent and have antimicrobial properties $[10,11]$. Chemical methods such as in situ reduction [12] and electrochemical deposition [13] are used for fixing nanoparticles onto dielectric surfaces. Among the physical methods used for deposition of thin films, magnetron sputtering stands as one of the most versatile, being intensively used in both research and industry [14]. Compared to chemical methods it is considered cleaner and more environmentally friendly, leaving no chemical residues or hazardous compounds. The use of high-power pulses in magnetron sputtering, as defined in HiPIMS [15,16], allows adding supplementary control over the properties of the thin film by using highly ionized fluxes that can be directed toward the substrate at variable fluxes and energies [17]. Compared to magnetron sputtering it has the advantage of providing precise control of the quantity by using the additional temporal parameters added by the pulsed regime, namely, the frequency and pulse duration.

Such thin films can be deposited onto self-adhesive polymer foils, adding additional functionalities such as antibacterial properties to the existing mechanical protection provided by such foils. In order to keep the transparency of the coatings, one needs to limit the amount of silver on the surface and to avoid coalescence by confining the metal only in isolated nanosized particles. On the other hand, for achieving antimicrobial efficacy of these layers it is usually necessary to ensure a prolonged release of the silver biocide at a concentration level (0.1 ppb) [18] needed to provide a sufficient amount.

\section{Materials and Methods}

The method we used for obtaining the thin films was magnetron sputtering. A confocal configuration with 3 targets of 1 inch diameter was used. This configuration allowed us to deposit each material individually, to make multilayer structures, or to co-deposit 2 or 3 materials and mix them at the same time.

For the deposition, we used silicon oxide, titanium oxide, and silver targets. The substrates were made of thin self-adhesive polyurethane foils. The oxide targets were operated in RF sputtering conditions, at $50 \mathrm{~W}$ applied power on each of the targets. The deposition was performed in argon at 6 mTorr pressure, and the deposition rates were chosen so that the oxide remained the main material and the silver was only a small addition. The typical deposition time was $30 \mathrm{~min}$, yielding film thicknesses in the 30 to $35 \mathrm{~nm}$ range.

For the fine tuning of the deposition rate for Ag, HiPIMS was used to sputter the Ag. The pulse characteristics selected for the deposition of Ag are illustrated in Figure 1. The pulse voltage was set at $650 \mathrm{~V}$, with a peak current of $1.5 \mathrm{~A}$. Pulse duration was $50 \mu \mathrm{s}$, and the repetition frequency was varied in the 1 to $10 \mathrm{~Hz}$ range. 


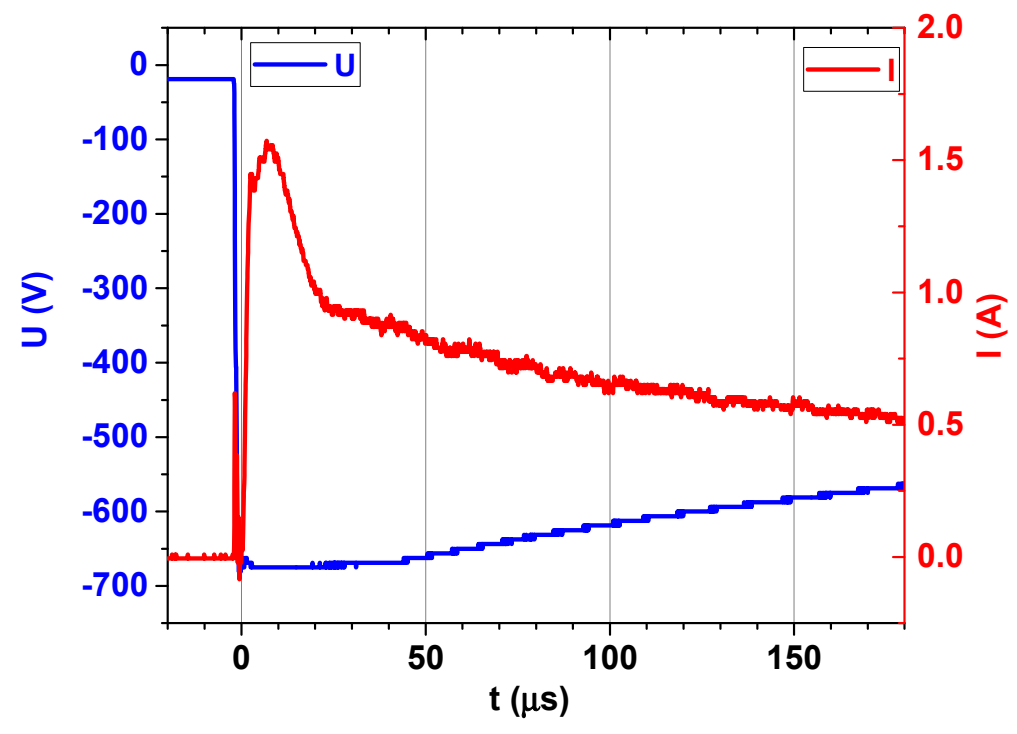

Figure 1. Typical HiPIMS voltage and current pulse shapes used for the deposition of Ag under HiPIMS conditions.

The topography of thin films was analyzed based on AFM images acquired with the AFM/STM Microscopy System (INNOVA VEECO, Berlin, Germany) working in taping mode. UV-spectrophotometry was performed using a Jasco V-670 UV-Vis/NIR Spectrophotometer (Tokyo, Japan). A SEM-Hitachi Tabletop Scanning Electron Microscope (TM3030, Tokyo, Japan) system equipped with Energy Dispersive X-ray spectrometer (EDS, QUANTAX 70, Bruker, MS, USA) was used for the investigation of the composition of the thin films. The crystalline structure was examined using a SmartLab (RIGAKU, Tokyo, Japan) diffractometer equipped with a $\mathrm{Cu}$ rotating anode $(9 \mathrm{~kW})$ and vertical goniometer with 5 axes. High resolution optics of the incident beam was used to obtain $\mathrm{Cu} \mathrm{Ka1}(\lambda=1.540597 \AA)$ radiation. The measurements were performed in the $2 \theta$ interval $10-100^{\circ}$, using an incidence angle of $1^{\circ}$, at a scanning speed of $3^{\circ} / \mathrm{min}$. The grain sizes of the investigated samples were calculated using the Scherrer Equation (1):

$$
\text { Grain Size }=\frac{0.9 \lambda}{\beta \cos \theta}
$$

where $\lambda$ represents the diffraction wavelength; $\beta$ represents the full width at half maximum intensity of the peak (in radians); $\theta$ represents the Bragg angle (in degrees).

The antibacterial performance of films was evaluated against Escherichia coli strains (ATCC 25922) according to ISO 22196:2011 [19] but with some modifications made depending on the type of films tested as described in the following. The strains were cultured on blood agar for $24 \mathrm{~h}$ at $37^{\circ} \mathrm{C}$ before use. The films were cut into round shapes $(\varnothing 15 \mathrm{~mm})$ and sterilized on both sides, for $15 \mathrm{~min}$ on each side at $60 \mathrm{~cm}$ distance using UVC light irradiation. The prepared inoculum of $10^{5}$ and $10^{4} \mathrm{CFU} / \mathrm{mL}(113 \mu \mathrm{L})$ was poured on each film. The contact time of the film with inoculum was performed at room temperature for $30 \mathrm{~min}$. Afterward, the suspension and the film were washed in $3 \mathrm{~mL}$ of saline solution. The washed solution was dispersed on a Petri dish with blood agar. Incubation of plates was then carried out at $37^{\circ} \mathrm{C}$ for 24 and $48 \mathrm{~h}$. The number of Escherichia coli colonies was quantified using the automatic analyzer (InterScience Scan 300-Soft Scan Saint Nom la Brétèche, France). The number of colonies were reported as colony forming units (CFUs). Duplicate measurements were performed. 
The results were then tabulated and the means and standard deviations between the two experiments were calculated, respectively, and the antibacterial efficiency compared to the films on which the bacteria were deposited using Equation (2) [20]:

$$
\text { Antimicrobial Activity }(\%)=\frac{\mathrm{N}_{\mathrm{c}}-\mathrm{N}_{\mathrm{s}}}{\mathrm{N}_{\mathrm{c}}} \cdot 100
$$

where $\mathrm{N}_{\mathrm{c}}$ represents the number of colonies on the control films; $\mathrm{N}_{\mathrm{s}}$ represents the number of colonies on the tested films.

\section{Results}

\subsection{Thin Film Deposition and Characterization}

\subsubsection{Sample Preparation}

The polyurethane foils were cleaned in isopropyl alcohol prior to deposition and a plasma cleaning procedure was carried out prior to each deposition. The plasma cleaning consisted of applying an RF bias on the substrate, with $50 \mathrm{~V} \mathrm{DC}$ self-bias, at 6 mTorr of Argon pressure, for a duration of $15 \mathrm{~min}$.

The topography of the foils before cleaning showed a nanopatterning with roughly $500 \mathrm{~nm}$ radius holes distributed on the surface, a few nanometers deep (Figure 2). After the cleaning procedures, one can see that the nanopattern was kept, with a small increase in surface roughness in between the holes. Additional testing with higher voltages and longer processing duration was performed. It was found that if the voltage was too high and/or the duration too long, the surface of the polymer changed dramatically. Therefore, the cleaning conditions for all the deposited samples was kept at $50 \mathrm{~V}$ of DC self-bias and 15 min process duration.

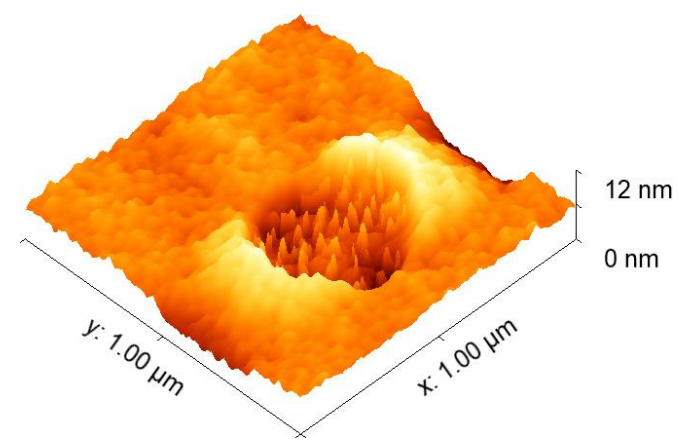

(a)

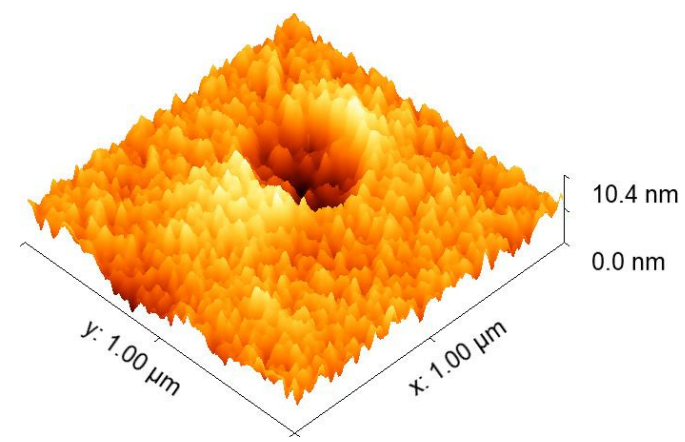

(c)

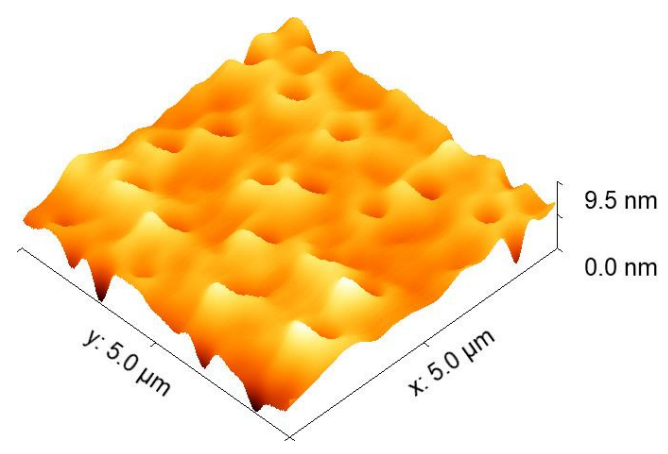

(b)

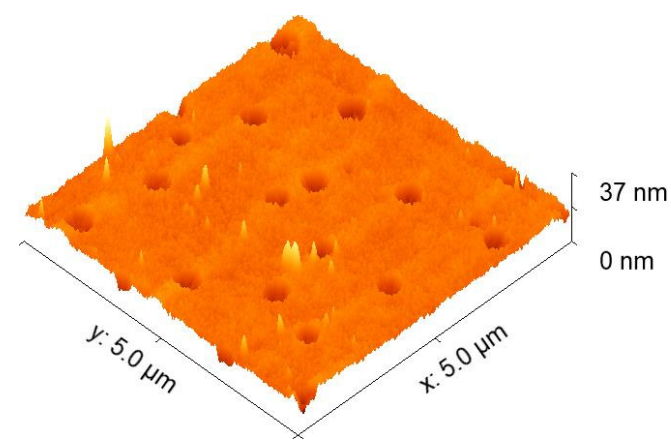

(d)

Figure 2. AFM images of the polymer surface before $(\mathbf{a}, \mathbf{b})$ and after the plasma cleaning procedure $(\mathbf{c}, \mathbf{d})$. The images correspond to the same sample, at different scanning areas.

Regarding the depth of the holes, it was observed that after cleaning, the depth slightly increased from $4.16 \pm 0.74$ to $6.44 \pm 2.66 \mathrm{~nm}$. These values were calculated by averaging the depth of all holes found on surfaces recorded on $25 \mu \mathrm{m}^{2}$ (Figure $2 \mathrm{~b}-\mathrm{d}$ ). The same result 
can also be seen in the case of holes presented in Figure $2 \mathrm{a}-\mathrm{c}$, indicating that the cleaning process affected the surface of foils by deepening the already existing holes.

The changes induced in the optical properties of the polymer were investigated by UV-Vis Spectrophotometry. The transmittance, reflectivity, and absorbance of the samples before and after cleaning are represented in Figure 3. The transparency of the foil was diminished from 90 to $85 \%$, whereas the reflectivity remained almost constant. This means that the appearance of the foil did not change significantly. The reduction of transmittance was almost entirely due to the increase in absorption.

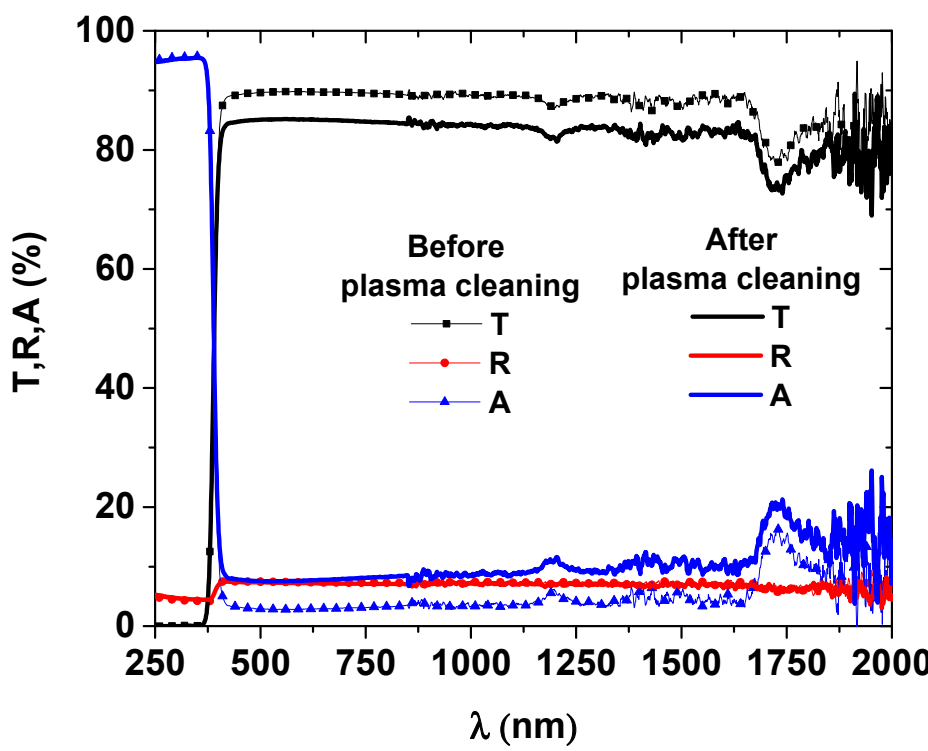

Figure 3. Spectrophotometric curves of the polymer foil sample before and after plasma cleaning at $50 \mathrm{~V}$ for $15 \mathrm{~min}$ (T-transmittance, R-reflectivity, A-absorbance).

\subsubsection{Deposition Process and Physical Characterization}

The main challenge for the deposition of transparent coatings with sufficient antimicrobial activity is to find the balance between the maximum quantity of metal atoms that do not reduce drastically the transmittance and the minimum quantity required to obtain the antimicrobial effect. Therefore, the deposition rates of the materials to be deposited and the deposition time should be adapted so that the total quantity of metal atoms remains within these constrains. The deposition rate of $\mathrm{SiO}_{2}$ and $\mathrm{TiO}_{2}$ was $\sim 1 \mathrm{~nm} / \mathrm{min}$, and the process duration was fixed at $30 \mathrm{~min}$.

In order to find the optimum quantity of silver to be embedded in the oxide matrix, the frequency of the HiPIMS pulses was changed between 1 and $10 \mathrm{~Hz}$, and the Ag films were deposited on the polymer substrate for a total duration of $30 \mathrm{~min}$. The AFM images of the Ag thin films deposited on the polymer surface are represented in Figure 4. One important feature that emerges from these images is that the deposition followed the topography of the polymer foil, with preferential growths in the places where the circular patterns were present. The roughness of the surface increased with increasing frequency, with a visible increase in the grain size on the surface. At a frequency of $10 \mathrm{~Hz}$, the $\mathrm{Ag}$ films covered almost entirely the initial pattern on the surface, creating a continuous film. The thickness of the Ag layer obtained at $10 \mathrm{~Hz}$ was $30 \mathrm{~nm}$, making it equal to the envisaged thickness of the oxide deposited in a similar duration. The thicknesses of the samples obtained at 1 and $3 \mathrm{~Hz}$, respectively, were not directly evaluated, being too small to obtain reliable results. Nevertheless, a direct relation with the frequency should be considered, accounting for an equivalent deposition rate of $3 \mathrm{~nm}$ per $1 \mathrm{~Hz}$. 


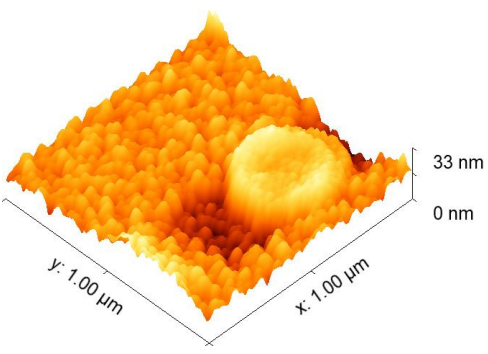

(a)

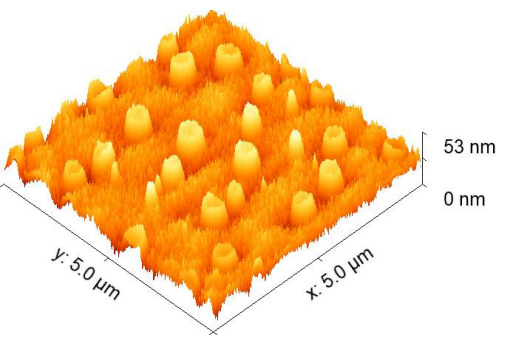

(d)

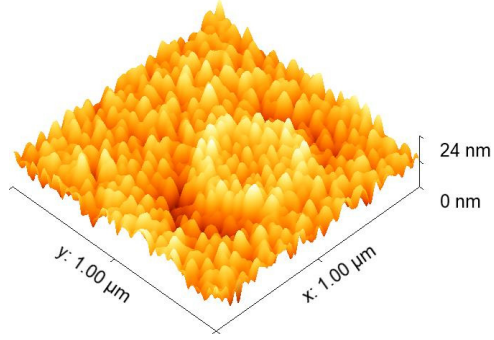

(b)

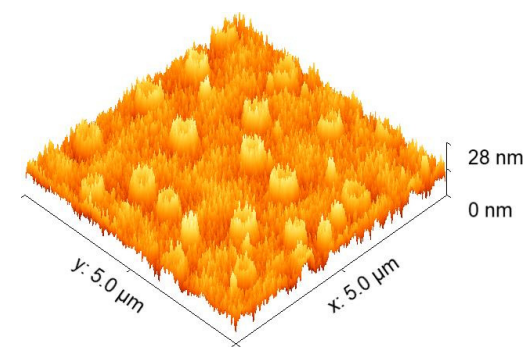

(e)

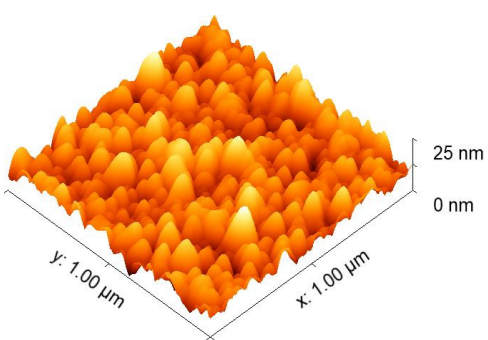

(c)

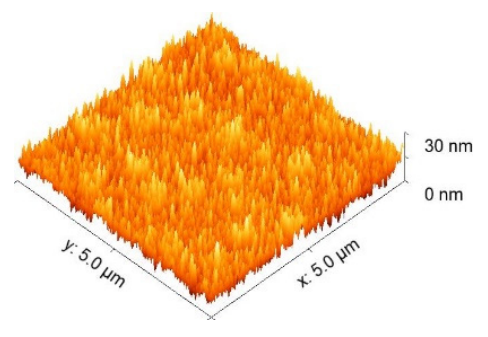

(f)

Figure 4. AFM images of the polymer foils deposited with Ag films, for a period of $30 \mathrm{~min}$ and at different frequencies: $1 \mathrm{~Hz}(\mathbf{a}, \mathbf{d}), 3 \mathrm{~Hz}(\mathbf{b}, \mathbf{e})$, and $10 \mathrm{~Hz}(\mathbf{c}, \mathbf{f})$. The images are grouped by deposition conditions corresponding to the same sample and were obtained at different scanning areas.

The XRD spectra obtained for the same samples are presented in Figure 5, demonstrating the presence of crystalline Ag (identified based on JCDPS No.1-071-4613) with cubic structure and (111) preferential orientation. There is a clear dependency of the crystallinity on the deposition frequency, since by increasing the frequency, the crystalline films were obtained. This finding was well evident for the film deposited at $10 \mathrm{~Hz}$. For the films prepared at $1 \mathrm{~Hz}$, the peak located at $38.3^{\circ}$ broadened, indicating a low crystallinity, tending to be amorphous. One may also observe an increase in grain size from $1.07 \mathrm{~nm}$ (for Ag at $1 \mathrm{~Hz}$ ) up to $9.42 \mathrm{~nm}$ (for Ag at $10 \mathrm{~Hz}$ ), as seen in Table 1. This increase in peak intensity and crystallinity can be attributed to the film thickness effects [21].

The next experimental step was to deposit simultaneously $\mathrm{Ag}$ and two oxides, $\mathrm{SiO}_{2}$ and $\mathrm{TiO}_{2}$, respectively, which was done because of mechanical stresses caused by cell compression and the oxidation occurring on the surface of silver. Because of the constrains related to the transparency of the film, the quantity of $\mathrm{Ag}$ must be limited to a minimum. Therefore, the HiPIMS sputtering was set at $1 \mathrm{~Hz}$ and the total process duration at $30 \mathrm{~min}$. It was seen in Figure 6 that when Ag was found in an amorphous matrix of $\mathrm{SiO}_{2}$ and $\mathrm{TiO}_{2}$, respectively, there was a shift of the peak maximum toward higher values, indicating the existence of compressive stress. Taking also into account the oxide matrix surrounding the Ag clusters and the atomic radius of $\mathrm{O}_{2}(0.73 \AA)$ and $\mathrm{Ag}(1.445 \AA)$ [22], one may conclude that a partial oxidation of the silver occurred, the elementary cell being compressed by the forming compound. Moreover, there were shifts of $2.47^{\circ}$ and $1.66^{\circ}$ between the standard peak and the one registered for $\mathrm{Ag}+\mathrm{SiO}_{2}$ and $\mathrm{Ag}+\mathrm{TiO}_{2}$, respectively. Although the quantity of Ag embedded in the thin film was very small, comparable with the one corresponding to the $1 \mathrm{~Hz}$ deposition, the grain sizes of $\mathrm{Ag}$ embedded in the $\mathrm{SiO}_{2}$ and $\mathrm{TiO}_{2}$ matrices were significantly higher than the ones obtained for bare silver at 1,3 , and $10 \mathrm{~Hz}$ deposition frequencies. According to the data in literature, an amorphous matrix allows Ag to diffuse more easily and to form larger size Ag nanoparticles [23]. Considering that only the maximum $\mathrm{Ag}$ peak could be identified in the $\mathrm{Ag}+\mathrm{SiO}_{2}$ and $\mathrm{Ag}+\mathrm{TiO}_{2}$ films, it results that the Ag was finely dispersed in the amorphous matrix [24]. According to Adochite et al., Ag was finely dispersed in the amorphous matrix, since only the maximum $\mathrm{Ag}$ peak could be identified in the $\mathrm{Ag}+\mathrm{SiO}_{2}$ and $\mathrm{Ag}+\mathrm{TiO}_{2}$ films [24]. Moreover, the fact that Ag prevented the crystallization of anatase phase, as indicated by XRD patterns of 
as-deposited $\mathrm{Ag}+\mathrm{TiO}_{2}$ nanocomposite films in the mentioned study, also represented an indication of Ag dispersion. This effect was attributed by Okumu et al. [25] to the impinging energetic oxygen ions which were formed during sputtering of $\mathrm{Ag}: \mathrm{TiO}_{2}$ films.

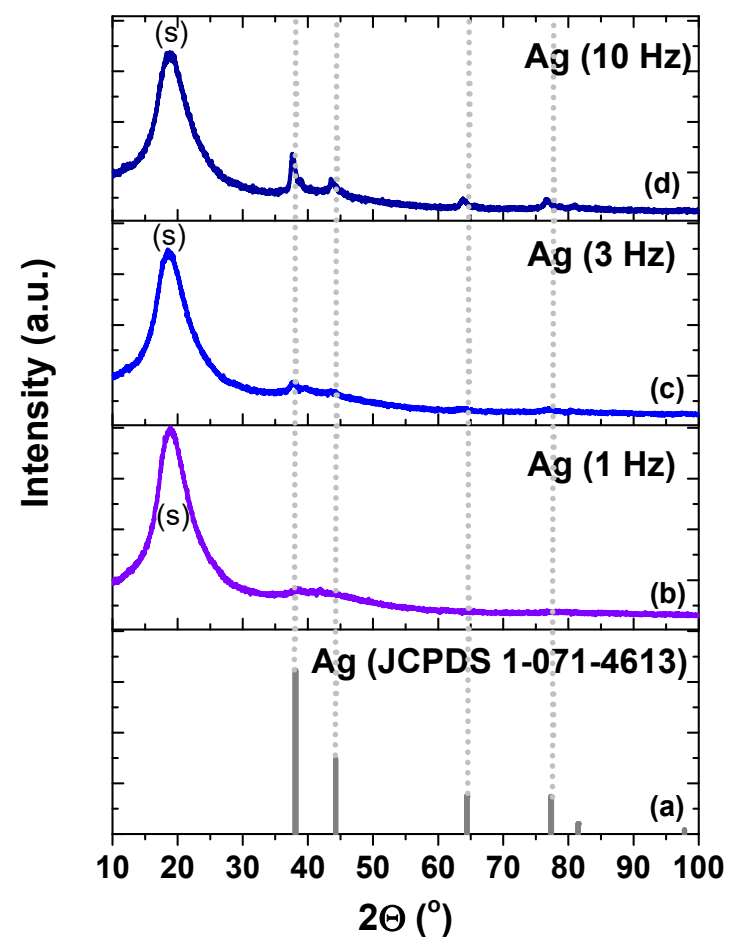

Figure 5. XRD spectra for the Ag thin films obtained at different pulse frequencies $1 \mathrm{~Hz}(\mathbf{b}), 3 \mathrm{~Hz}(\mathbf{c})$, $10 \mathrm{~Hz}(\mathbf{d})$. The position of Ag peaks in the JCPDS card is depicted in (a).

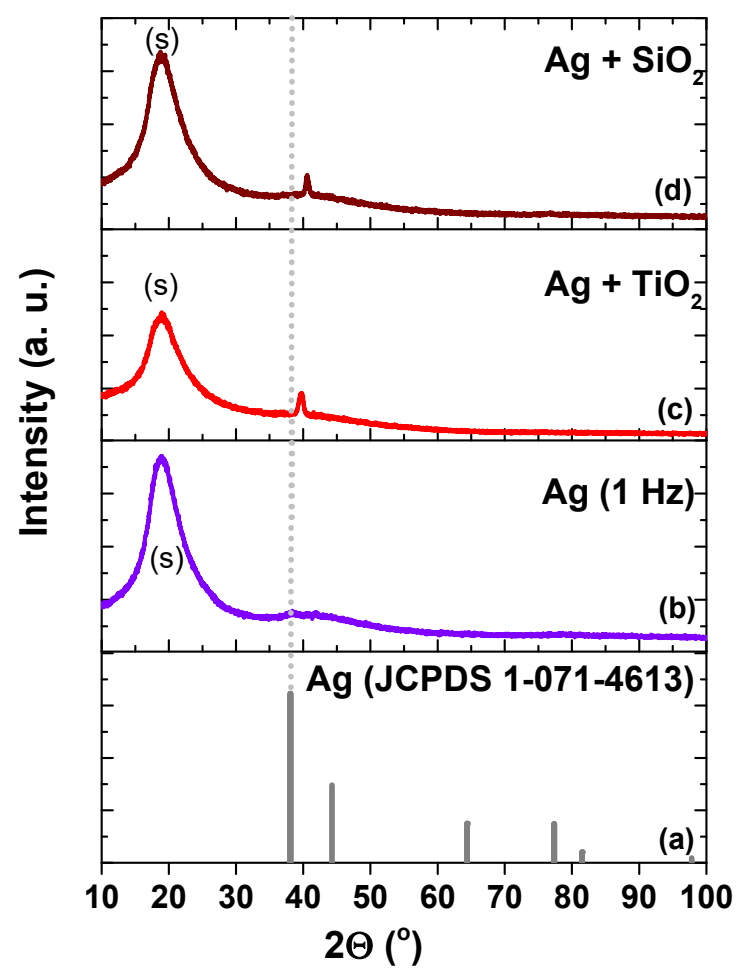

Figure 6. XRD spectra of thin films obtained during 30 min sputtering of Ag at $1 \mathrm{~Hz}$, without any oxide (b), with $\mathrm{TiO}_{2}$ (c), and with $\mathrm{SiO}_{2}$ (d), respectively. The position of Ag peaks in the JCPDS card is depicted in (a). 
Table 1. Maximum peak position for Ag (111) (according to JCDPS no. 1-071-4613 card), the equivalent position of measured maxima and the grain size of the investigated samples.

\begin{tabular}{ccc}
\hline Sample & Peak Position (111) $\left.\mathbf{(}^{\circ}\right)$ & Grain Size (nm) \\
\hline $\mathrm{Ag}(\mathrm{JCPDS} 01-071-4613)$ & 38.1 & $\mathrm{NA}$ \\
$\mathrm{Ag}(1 \mathrm{~Hz}, 30 \mathrm{~min})$ & 38.3 & 1.07 \\
$\mathrm{Ag}(3 \mathrm{~Hz}, 30 \mathrm{~min})$ & 37.64 & 1.53 \\
$\mathrm{Ag}(10 \mathrm{~Hz}, 30 \mathrm{~min})$ & 37.63 & 9.42 \\
$\mathrm{Ag}+\mathrm{SiO}_{2}$ & 40.57 & 16.6 \\
$\mathrm{Ag}+\mathrm{TiO}_{2}$ & 39.76 & 12.12 \\
\hline
\end{tabular}

For the silver-containing films, only $10 \%$ of equivalent Ag thickness was used, compared with the oxide thin film, i.e., $\sim 3$ vs. $30 \mathrm{~nm}$. A version of only the oxide thin film was also made by combining two oxides in equal amounts to form a $\sim 30 \mathrm{~nm}$ thick film, obtained during a 15 min deposition process. The AFM images of these 3 types of thin films are presented in Figure 7. These functional films combine two materials but keep the ensemble thin enough to maintain the initial surface features. It can be clearly seen that there is a preferential growth that follows the initial pattern of the polymer film.

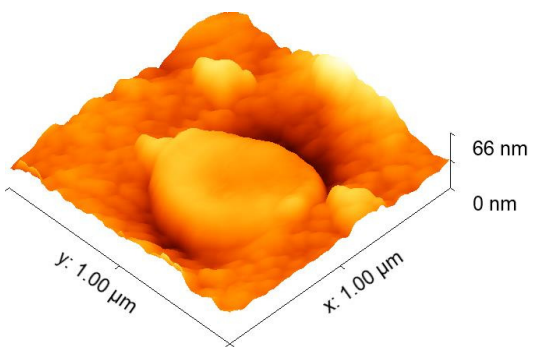

(a)

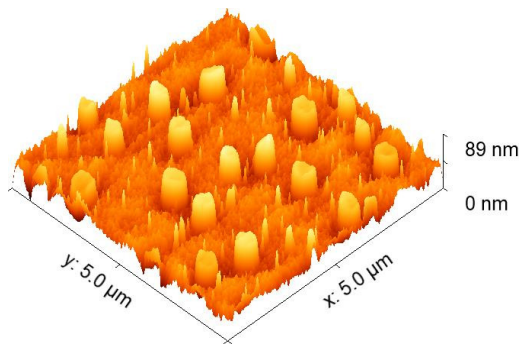

(d)

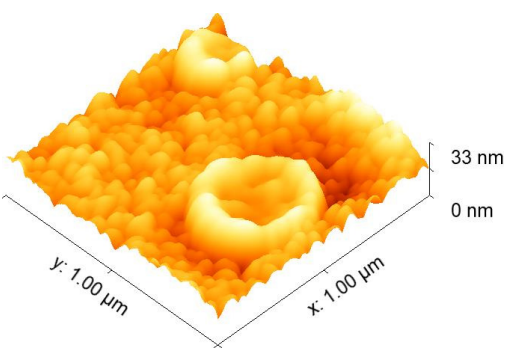

(b)

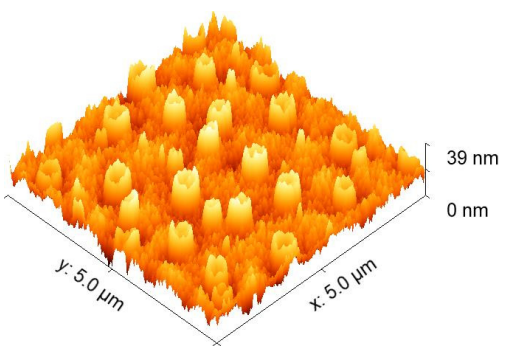

(e)

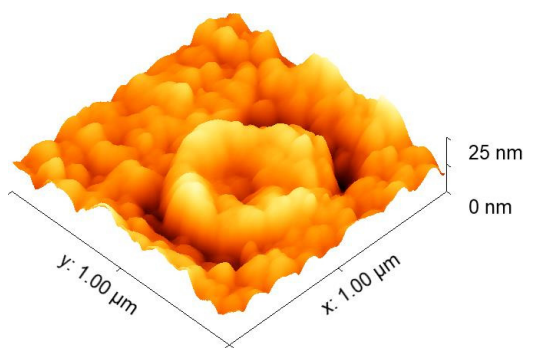

(c)

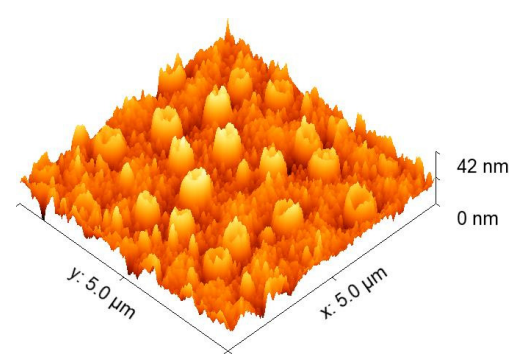

(f)

Figure 7. AFM images of the polymer foils deposited with $\mathrm{TiO}_{2}+\mathrm{Ag}$ films (a,d), $\mathrm{SiO}_{2}+\mathrm{TiO}_{2}$; (b,e), $\mathrm{SiO}_{2}+\mathrm{Ag}$; (c,f); all films have a total thickness of $\sim 33 \mathrm{~nm}$. The images grouped by type of thin film correspond to the same sample and were obtained at different scanning areas.

The optical properties of the resulting structure are very important for this application since the foil is applied directly on the phone screen and should keep its transparency and general appearance. From the transmission and reflection spectrum presented in Figure 8, one can see that the $\mathrm{SiO}_{2}$ film had the best transparency of all. Titanium oxide, on the other hand, had the lowest transparency, most probably because of an insufficient amount of oxygen, leading to sub-stoichiometric composition.

From the absorption spectra, it is evident that an absorption peak around $450-500 \mathrm{~nm}$ was present for the silver-containing films. This was specific to the absorption on silver nanoparticles, associated with the surface plasmon resonance phenomena [26]. The position of the peak depends on the matrix, showing a potential way of tuning the size and density of particles by embedding them in different matrices. The presence of this peak confirmed the $\mathrm{Ag}$ nanoparticle were finely dispersed in the oxide matrix. 


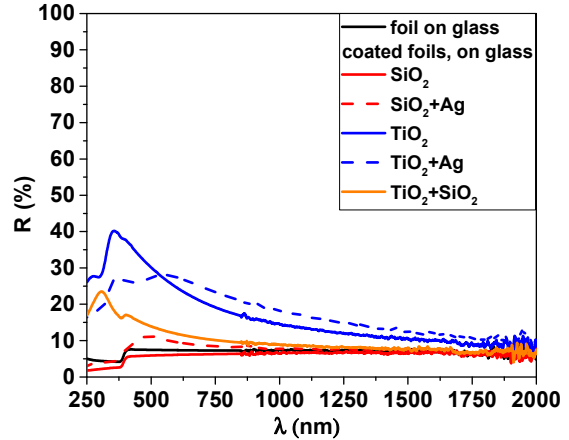

(a)

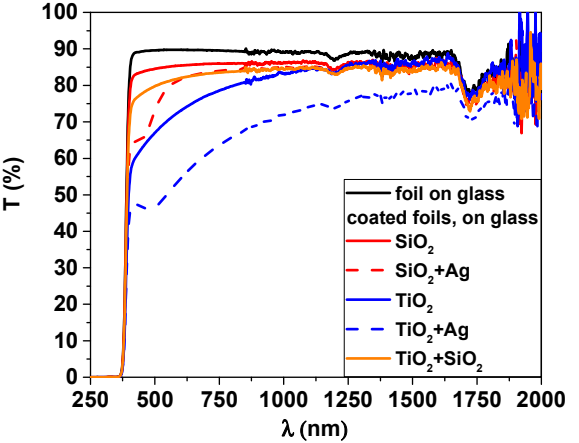

(b)

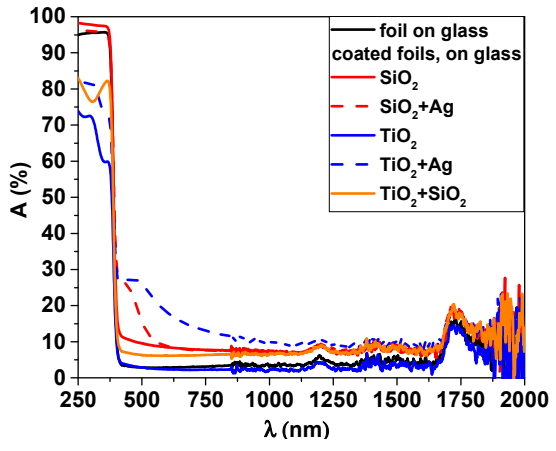

(c)

Figure 8. Spectrophotometric curves, reflectivity (a), transmittance (b) and absorbance (c) of the uncoated foil and the foils coated with $\mathrm{SiO}_{2}, \mathrm{SiO}_{2}+\mathrm{Ag}, \mathrm{TiO}_{2}, \mathrm{TiO}_{2}+\mathrm{Ag}, \mathrm{TiO}_{2}+\mathrm{SiO}_{2}$.

The film composition was assessed by EDX (Figure 9). Although very thin, a measurable amount for $\mathrm{Ag}$ was detected, accounting for only 0.1 to $0.2 \%$ of the total. Nevertheless, the silver represented 23 and $28 \%$ as compared with $\mathrm{Si}$ and $\mathrm{Ti}$, respectively. In Figure 9, the elemental distribution is also presented. One can see that each constitutive element of each investigated layer was well distributed on the investigated area, indicating that the layers were homogeneously coated on the whole surface of the foil.
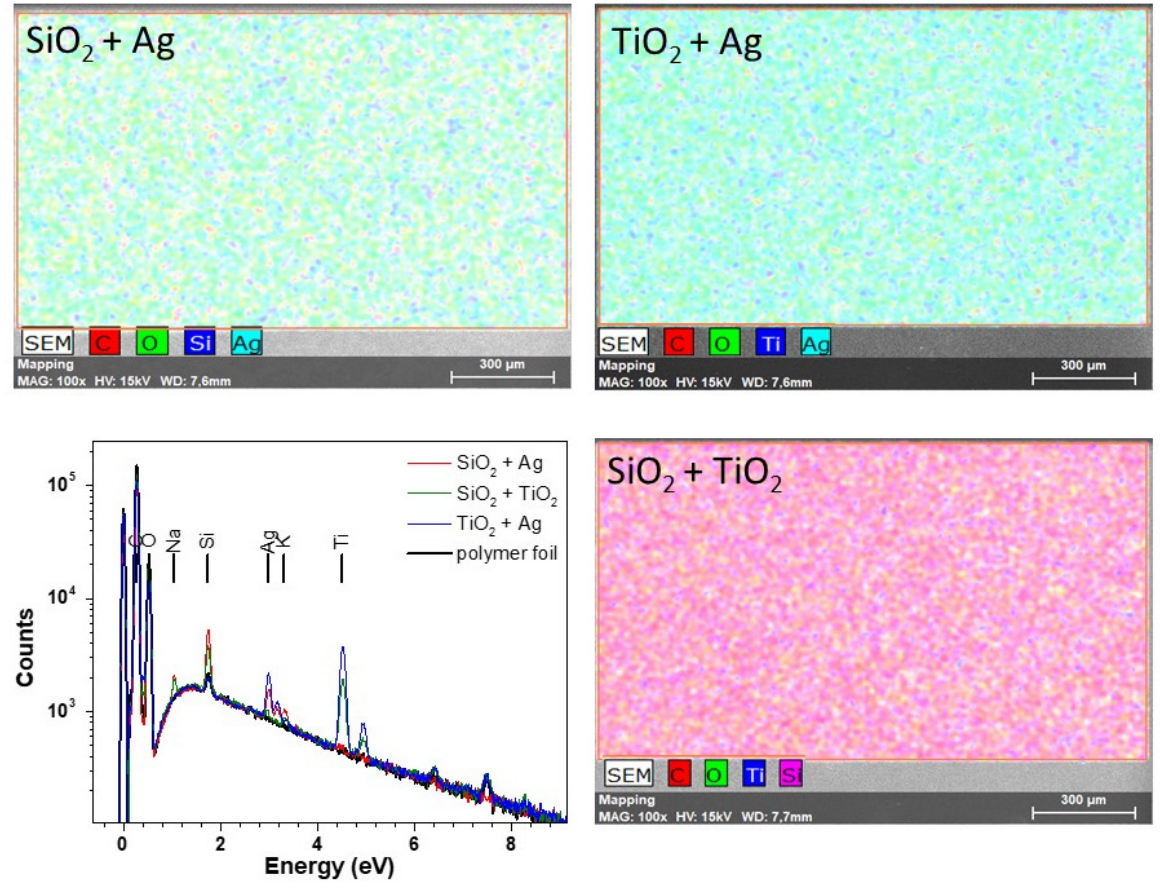

Figure 9. EDX spectra and element distribution of the polymer foils and the foils deposited with $\mathrm{TiO}_{2}+\mathrm{Ag}$ films, $\mathrm{SiO}_{2}+\mathrm{TiO}_{2}, \mathrm{SiO}_{2}+\mathrm{Ag}$; all films have a total thickness of $\sim 33 \mathrm{~nm}$.

\subsection{Antimicrobial Activity}

The antimicrobial activity of all three types of layers was assessed using the methodology described in the Materials and Methods section. The graphs in Figure 10 show the difference between the results read at 24 and $48 \mathrm{~h}$, respectively, for all of the investigated layer types in contact with Escherichia coli suspensions of concentrations $10^{5} \mathrm{CFU} / \mathrm{mL}$ and $10^{4} \mathrm{CFU} / \mathrm{mL}$. A maximum efficiency of almost $97 \%$ was obtained for samples deposited with $\mathrm{SiO}_{2}+\mathrm{Ag}$ at a concentration of $10^{4} \mathrm{CFU} / \mathrm{mL}$. Silver's antibacterial properties can be explained by the following mechanism: owing to the sulfur-Ag affinity, the bacterial cell membrane is enriched with sulfur-containing proteins, which could be favored locations 
for Ag particle attachment. Hence, silver nanoparticles can damage or affect the structure of bacteria by attaching to the bacterial cell membrane $[27,28]$.

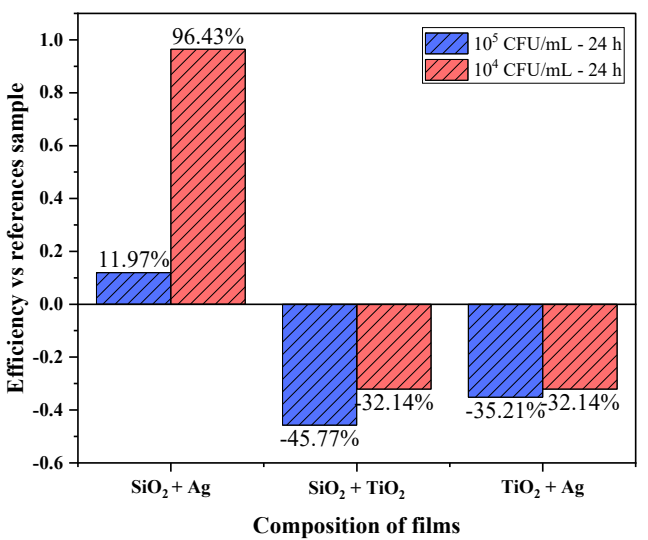

(a)

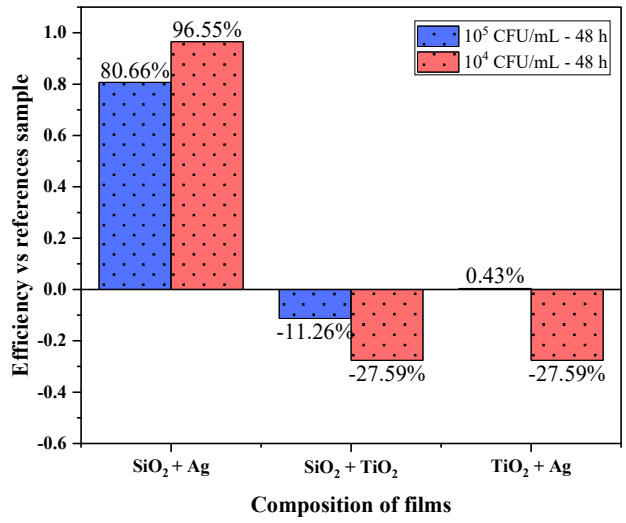

(b)

Figure 10. Antimicrobial efficiency of $\mathrm{SiO}_{2}+\mathrm{Ag}, \mathrm{SiO}_{2}+\mathrm{TiO}_{2}, \mathrm{TiO}_{2}+\mathrm{Ag}$ films against Escherichia coli, at two concentrations of $10^{5}$ and $10^{4} \mathrm{CFU} / \mathrm{mL}$ and two incubation times of 24 (a) and $48 \mathrm{~h}(\mathbf{b})$.

On the other hand, for the other two films submitted with $\mathrm{SiO}_{2}+\mathrm{TiO}_{2}$ and $\mathrm{TiO}_{2}+\mathrm{Ag}$ under the tested conditions, there was an increased growth compared to the reference sample, the polymer foil without any deposited layer. At $24 \mathrm{~h}$ of incubation, for the film submitted with $\mathrm{SiO}_{2}+\mathrm{TiO}_{2}$, an increase of $45.77 \%$ in the growth of bacterial colonies was observed compared to the reference sample for the concentration of $10^{5} \mathrm{CFU} / \mathrm{mL}$, while the concentration of $10^{4} \mathrm{CFU} / \mathrm{mL}$ for the same experimental conditions recorded a percentage of $32.14 \%$ over the number of colonies in the reference sample. Studies show low antibacterial properties for $\mathrm{TiO}_{2}$ and $\mathrm{SiO}_{2}$. Two very important factors influencing the antibacterial grade are the size of the nanoparticles used [29] and the inoculation method, which, being photocatalytic materials, has been shown in the presence of $\mathrm{UV}_{-} \mathrm{TiO}_{2}$ radiation to enhance the antibacterial efficiency for Gram-negative bacterial species [30].

Because $\mathrm{TiO}_{2}$ is a photocatalytic material that has activity in UV-radiation, to make it active and in the visible spectrum, it must be doped with transition metals such as $\mathrm{Ag}$, $\mathrm{V}, \mathrm{Cr}, \mathrm{Mn}, \mathrm{Fe}, \mathrm{Co}$, or $\mathrm{N}$. In the case of films deposited with $\mathrm{TiO}_{2}+\mathrm{Ag}$, bacterial activity increased in both Escherichia coli concentrations [31].

Figure $10 \mathrm{~b}$ indicates abundant bacterial growth resulting in a percentage of $80.66 \%$ for the antimicrobial efficiency of the sample deposited with $\mathrm{SiO}_{2}+\mathrm{Ag}$ at the concentration of $10^{5} \mathrm{CFU} / \mathrm{mL}$. For the concentration of $10^{4} \mathrm{CFU} / \mathrm{mL}$ the increasing trend was maintained, nearly maximum antibacterial efficiency, but the samples deposited with $\mathrm{SiO}_{2}+\mathrm{TiO}_{2}$ had the same proliferative effect as reading the plates at $24 \mathrm{~h}$. As a result, we observed that at the concentration of $10^{4} \mathrm{CFU} / \mathrm{mL}$ there were determined percentages that indicated an increased efficiency compared to the experiments performed at the concentration of $10^{5} \mathrm{CFU} / \mathrm{mL}$. In the case of blood agar plates incubated and evaluated after $48 \mathrm{~h}$, given the determined antibacterial efficacy, early senescence phenomena could be observed, phenomena that needed to be deepened to find a mechanism between the variability of the incubation time and the materials deposited on the polymer films.

\section{Discussion}

To summarize, we evaluated three types of thin films to be applied on self-adhesive polymer foils for smartphone applications. Among these, the one consisting of the combination of silicon oxide and silver was the most efficient.

We managed to maintain the surface characteristics of the original foil, obtaining a good transparency, and made evident the presence of nanostructured Ag nanoparticles embedded in the silicon oxide matrix. 
For films deposited with $\mathrm{TiO}_{2}+\mathrm{SiO}_{2}$ and those with $\mathrm{TiO}_{2}+\mathrm{Ag}$, the microbiological activity of Escherichia coli indicated an increased growth of both bacterial concentrations. $\mathrm{SiO}_{2}+\mathrm{Ag}$ films had an elevated antibacterial activity of $10^{4} \mathrm{CFU} / \mathrm{mL}$, indicating according to Zhao et al. [32] that Ag can form complexes with DNA and RNA resulting in DNA condensation and replication inhibition, as established in other investigations. Silver interaction with thiol groups in proteins can result in inactivation of respiratory enzyme function [33]. Antimicrobial actions can be represented by free radicals produced on silver particles, particularly reactive oxygen species (ROS) [34].

$\mathrm{SiO}_{2}+\mathrm{Ag}$ films exhibited a high effect on the Escherichia coli bacteria. The efficiency could usually be related to the grain size, with size effects that were identified both at micro and nano scales. For the microscale range, it has already been demonstrated that bacterial attachment depends significantly on the size of particles [35]. Several researchers have reported that bacteria tend to attach to larger particles because they exhibit a larger surface that provides more attachment sites, which permit more attached cells. For example, Soupir et al. reported that at least $60 \%$ of attached Escherichia coli and enterococci were related to particles smaller than $62 \mu \mathrm{m}$ [36]. Jeng et al. demonstrated that more than $90 \%$ of Escherichia coli were attached to particles with sizes ranging from 5 to $30 \mu \mathrm{m}$ [37]. A similar result was published by George et al., who showed that the percentage of attached Escherichia coli bacteria is related to particles larger than $5 \mu \mathrm{m}$ and increases with particle concentration [38]. Moreover, Oliver et al. reported that the Escherichia coli bacteria prefers attachment to particles ranging from 16 to $32 \mu \mathrm{m}$, without explaining this mechanism [39].

Related to the nanoscale range, on the other hand, it was observed that the lower values, up to $5 \mathrm{~nm}$, were more likely for the inhibition of the Escherichia coli bacteria. Ahmed et al. found that the inactivation of Escherichia coli under ultraviolet light irradiation of the $\mathrm{TiO}_{2}$ surface can be attributed to the reduction of the crystallite size from the 30 to $5 \mathrm{~nm}$ [40]. Furthermore, the study of Ahmed et al. was in good agreement with others who agreed that the degradation efficiency of $\mathrm{TiO}_{2}$ nanoparticles depends on their morphology, preparation methods, and especially the size of the particles [41]. The challenge in preparation of nanoparticles of nanoscale size is to obtain smaller nanoparticles with homogeneous size distribution [40].

In the present paper it was shown that by using magnetron sputtering co-deposition, this homogeneity can be achieved, with grain sizes in the range of $\sim 10 \mathrm{~nm}$ scale. The larger grain size of $\mathrm{Ag}$ nanoparticles embedded in $\mathrm{SiO}_{2}$ as compared to the ones embedded in $\mathrm{TiO}_{2}$ appears to be beneficial for the increase in bactericidal effect. In perspective, the combination of these thin films with embedded Ag nanoparticles, with the effect of UV-radiation, can be envisaged as a way to increase the antibacterial effect.

Author Contributions: Conceptualization, C.V. and M.B.; methodology, A.C.P., M.D., M.E.I. and M.B.; formal analysis, A.C.P., M.D., L.R.C., I.P., S.C. and C.S.A.; investigation, A.C.P., M.D., I.P., A.E.K., L.R.C., L.E.T., C.S.A., S.C. and L.R.; writing-original draft preparation, C.V., C.S.A. and M.B.; writing-review and editing A.V., M.E.I., C.S.A. and M.B.; supervision, C.V. and M.B.; project administration, C.V. and M.B.; funding acquisition, C.V. and M.B. All authors have read and agreed to the published version of the manuscript.

Funding: This work was funded by the Romanian Ministry of Education and Research, CCCDIUEFISCDI, Project No. PN-III-P2-2.1-PED-2019-4966 PED 489 and No. PN-III-P1-1.1-TE-2019-1924 TE 105, within PNCDI III.

Acknowledgments: A.V. thanks Tomsk Polytechnic University within the framework of the Tomsk Polytechnic University-Competitiveness Enhancement Program grant. INOE co-authors also want to thank to Core Program, Project No. 18N/2019.

Conflicts of Interest: The authors declare no conflict of interest. The funders had no role in the design of the study; in the collection, analyses, or interpretation of data; in the writing of the manuscript, or in the decision to publish the results. 


\section{References}

1. Neely, A.N.; Maley, M.P. Survival of enterococci and staphylococci on hospital fabrics and plastic. J. Clin. Microbiol. 2000, 38, 724-726. [CrossRef] [PubMed]

2. Dancer, S.J. Importance of the environment in meticillin-resistant Staphylococcus aureus acquisition: The case for hospital cleaning. Lancet Infect. Dis. 2008, 8, 101-113. [CrossRef]

3. Martinez, J.A.; Ruthazer, R.; Hansjosten, K.; Barefoot, L.; Snydman, D.R. Role of environmental contamination as a risk factor for acquisition of vancomycin-resistant enterococci in patients treated in a medical intensive care unit. Arch. Intern. Med. 2003, 163, 1905-1912. [CrossRef]

4. Perez-Gavilan, A.; de Castro, J.V.; Arana, A.; Merino, S.; Retolaza, A.; Alves, S.A.; Francone, A.; Kehagias, N.; Sotomayor-Torres, C.M.; Cocina, D.; et al. Antibacterial activity testing methods for hydrophobic patterned surfaces. Sci. Rep. 2021, $11,6675$. [CrossRef]

5. Graveto, J.M.; Costa, P.J.; Santos, C.I. Cell Phone Usage By Health Personnel: Preventive Strategies to Decrease Risk of Cross Infection In Clinical Context. Texto Contexto Enferm. 2018, 27, e5140016. [CrossRef]

6. Elmanama, A.; Hassona, I.; Marouf, A.; Alshaer, G.; Ghanima, E.A. Microbial Load of Touch Screen Mobile Phones Used by University Students and Healthcare Staff. J. Arab Am. Univ. 2015, 1, 1-18. [CrossRef]

7. Kister, M.P.; Borowska, K.; Jodłowska-Jędrych, B.; Kister, K.A.; Drop, B. The potential role of cell phones in dissemination of bacteria in a healthcare setting. Our Dermatol. Online. 2016, 7, 219-224. [CrossRef]

8. Anees Ahmad, S.; Sachi Das, S.; Khatoon, A.; Tahir Ansari, M.; Afzal, M.; Saquib Hasnain, M.; Kumar Nayak, A. Bactericidal activity of silver nanoparticles: A mechanistic review. Mater. Sci. Energy Technol. 2020, 3, 756-769. [CrossRef]

9. Le Ouay, B.; Stellacci, F. Antibacterial activity of silver nanoparticles: A surface science insight. Nano Today 2015, 10, 339-354. [CrossRef]

10. Ivanova, T.; Harizanova, A.; Koutzarova, T.; Vertruyen, B. Optical and structural characterization of $\mathrm{TiO}_{2}$ films doped with silver nanoparticles obtained by sol-gel method. Opt. Mater. 2013, 36, 207-213. [CrossRef]

11. Varghese, S.; Elfakhri, S.; Sheel, D.W.; Sheel, P.; Bolton, F.J.; Foster, H.A. Novel antibacterial silver-silica surface coatings prepared by chemical vapour deposition for infection control. J. Appl. Microbiol. 2013, 115, 1107-1116. [CrossRef] [PubMed]

12. Salem, M.A.; Elsharkawy, R.G.; Ayad, M.I.; Elgendy, M.Y. Silver nanoparticles deposition on silica, magnetite, and alumina surfaces for effective removal of Allura red from aqueous solutions. J. Solgel Sci. Technol. 2019, 91, 523-538. [CrossRef]

13. Yin, D.; Liu, Y.; Chen, P.; Meng, G.; Huang, G.; Cai, L.; Zhang, L. Controllable synthesis of silver nanoparticles by the pulsed electrochemical deposition in a forced circulation reactor. Int. J. Electrochem. Sci. 2020, 15, 3469-3478. [CrossRef]

14. Baptista, A.; Silva, F.J.G.; Porteiro, J.; Míguez, J.L.; Pinto, G.; Fernandes, L. On the Physical Vapour Deposition (PVD): Evolution of Magnetron Sputtering Processes for Industrial Applications. Proc. Procedia Manuf. 2018, 17, 746-757. [CrossRef]

15. Anders, A. Tutorial: Reactive high power impulse magnetron sputtering (R-HiPIMS). J. Appl. Phys. 2017, 121, 171101. [CrossRef]

16. Britun, N.; Minea, T.; Konstantinidis, S.; Snyders, R. Plasma diagnostics for understanding the plasma-surface interaction in HiPIMS discharges: A review. J. Phys. D Appl. Phys. 2014, 47, 224001. [CrossRef]

17. Greczynski, G.; Lu, J.; Jensen, J.; Bolz, S.; Kölker, W.; Schiffers, C.; Lemmer, O.; Greene, J.E.; Hultman, L. A review of metal-ionflux-controlled growth of metastable TiAlN by HIPIMS/DCMS co-sputtering. Surf. Coat. Technol. 2014, 257, 15-25. [CrossRef]

18. Kumar, R.; Münstedt, H. Silver ion release from antimicrobial polyamide/silver composites. Biomaterials 2005, 26, 2081-2088. [CrossRef]

19. ISO. Measurement of Antibacterial Activity on Plastics and Other Non-Porous Surfaces; ISO 22196; ISO: Geneva, Switzerland, 2011.

20. Al-Sharqi, A.; Apun, K.; Vincent, M.; Kanakaraju, D.; Bilung, L.M. Enhancement of the antibacterial efficiency of silver nanoparticles against gram-positive and gram-negative bacteria using blue laser light. Int. J. Photoenergy 2019, 2019, 2528490. [CrossRef]

21. Jalili, S.; Hajakbari, F.; Hojabri, A. Effect of silver thickness on structural, optical and morphological properties of nanocrystalline $\mathrm{Ag} / \mathrm{NiO}$ thin films. J. Theor. Appl. Phys. 2018, 12, 15-22. [CrossRef]

22. Guo, S.; Liu, C.T. Phase stability in high entropy alloys: Formation of solid-solution phase or amorphous phase. Prog. Nat. Sci. Mater. 2011, 21, 433-446. [CrossRef]

23. Navabpour, P.; Ostovarpour, S.; Hampshire, J.; Kelly, P.; Verran, J.; Cooke, K. The effect of process parameters on the structure, photocatalytic and self-cleaning properties of $\mathrm{TiO}_{2}$ and $\mathrm{Ag}-\mathrm{TiO}_{2}$ coatings deposited using reactive magnetron sputtering. Thin Solid Films 2014, 571, 75-83. [CrossRef]

24. Adochite, R.C.; Munteanu, D.; Torrell, M.; Cunha, L.; Alves, E.; Barradas, N.P.; Cavaleiro, A.; Riviere, J.P.; Le Bourhis, E.; Eyidi, D.; et al. The influence of annealing treatments on the properties of $\mathrm{Ag}: \mathrm{TiO}_{2}$ nanocomposite films prepared by magnetron sputtering. Appl. Surf. Sci. 2012, 258, 4028-4034. [CrossRef]

25. Okumu, J.; Dahmen, C.; Sprafke, A.N.; Luysberg, M.; Von Plessen, G.; Wuttig, M. Photochromic silver nanoparticles fabricated by sputter deposition. J. Appl. Phys. 2005, 97, 094305. [CrossRef]

26. Xu, G.; Tazawa, M.; Jin, P.; Nakao, S.; Yoshimura, K. Wavelength tuning of surface plasmon resonance using dielectric layers on silver island films. Appl. Phys. Lett. 2003, 82, 3811-3813. [CrossRef]

27. Sarkheil, M.; Sourinejad, I.; Mirbakhsh, M.; Kordestani, D.; Johari, S.A. Application of silver nanoparticles immobilized on TEPA-Den- $\mathrm{SiO}_{2}$ as water filter media for bacterial disinfection in culture of Penaeid shrimp larvae. Aquac. Eng. 2016, 74, 17-29. [CrossRef] 
28. Zhang, H.; Chen, G. Potent antibacterial activities of $\mathrm{Ag} / \mathrm{TiO}_{2}$ nanocomposite powders synthesized by a one-pot sol-gel method. Environ. Sci. Technol. 2009, 43, 2905-2910. [CrossRef]

29. Adams, L.K.; Lyon, D.Y.; McIntosh, A.; Alvarez, P.J.J. Comparative toxicity of nano-scale $\mathrm{TiO}_{2}, \mathrm{SiO}_{2}$ and $\mathrm{ZnO}$ water suspensions Water Sci. Technol 2006, 54, 327-334. [CrossRef]

30. Levchuk, I.; Kralova, M.; Rueda-Márquez, J.J.; Moreno-Andrés, J.; Gutiérrez-Alfaro, S.; Dzik, P.; Parola, S.; Sillanpää, M.; Vahala, R.; Manzano, M.A. Antimicrobial activity of printed composite $\mathrm{TiO}_{2} / \mathrm{SiO}_{2}$ and $\mathrm{TiO}_{2} / \mathrm{SiO}_{2} / \mathrm{Au}$ thin films under UVA-LED and natural solar radiation. Appl. Catal. 2018, 239, 609-618. [CrossRef]

31. Ahmad Barudin, N.H.; Sreekantan, S.; Thong, O.M.; Sahgal, G. Antibacterial activity of $\mathrm{Ag}_{-} \mathrm{TiO}_{2}$ nanoparticles with various silver contents. Proc. Mater. Sci. Forum 2013, 756, 238-245. [CrossRef]

32. Zhao, J.X.; Zhang, B.P.; Li, Y.; Yan, L.P.; Wang, S.J. Optical and photocatalytic properties of $\mathrm{TiO}_{2} / \mathrm{Ag}_{-} \mathrm{SiO}_{2}$ nanocomposite thin films. J. Alloys Compd. 2012, 535, 21-26. [CrossRef]

33. Suwanchawalit, C.; Wongnawa, S.; Sriprang, P.; Meanha, P. Enhancement of the photocatalytic performance of Ag-modified TiO 2 photocatalyst under visible light. Ceram. Int. 2012, 38, 5201-5207. [CrossRef]

34. Kim, J.S.; Kuk, E.; Yu, K.N.; Kim, J.H.; Park, S.J.; Lee, H.J.; Kim, S.H.; Park, Y.K.; Park, Y.H.; Hwang, C.Y.; et al. Antimicrobial effects of silver nanoparticles. Nanomed. Nanotechnol. Biol. Med. 2007, 3, 95-101. [CrossRef] [PubMed]

35. Wu, T.; Zhai, C.; Zhang, J.; Zhu, D.; Zhao, K.; Chen, Y. Study on the attachment of Escherichia coli to sediment particles at a single-cell level: The effect of particle size. Water 2019, 11, 819. [CrossRef]

36. Soupir, M.L.; Mostaghimi, S.; Dillaha, T. Attachment of Escherichia coli and Enterococci to Particles in Runoff. J. Environ. Qual. 2010, 39, 1019-1027. [CrossRef]

37. Jeng, H.C.; England, A.J.; Bradford, H.B. Indicator organisms associated with stormwater suspended particles and estuarine sediment. J. Environ. Sci. Health-Part A Toxic/Hazard. Subst. Environ. Eng. 2005, 40, 779-791. [CrossRef]

38. George, I.; Anzil, A.; Servais, P. Quantification of fecal coliform inputs to aquatic systems through soil leaching. Water Res. 2004, 38, 611-618. [CrossRef]

39. Oliver, D.M.; Clegg, C.D.; Heathwaite, A.L.; Haygarth, P.M. Preferential attachment of Escherichia coli to different particle size fractions of an agricultural grassland soil. Water Air Soil Pollut. 2007, 185, 369-375. [CrossRef]

40. Ahmed, F.; Awada, C.; Ansari, S.A.; Aljaafari, A.; Alshoaibi, A. Photocatalytic inactivation of Escherichia coli under UV light irradiation using large surface area anatase $\mathrm{TiO}_{2}$ quantum dots. R. Soc. Open Sci. 2019, 6, 191444. [CrossRef]

41. Benabbou, A.K.; Derriche, Z.; Felix, C.; Lejeune, P.; Guillard, C. Photocatalytic inactivation of Escherischia coli. Appl. Catal. B Environ. 2007, 76, 257-263. [CrossRef] 